\title{
A Rare Case Presentation: Pyogenic Granuloma of the Penis with Literature Review
}

\author{
Serkan Akan* \\ Department of Urology, University of Health Sciences, Sultan Abdulhamid Han Training and Research Hospital, Turkey
}

Submission: May 08, 2018; Published: May 16, 2018

*Corresponding author: Serkan Akan, Department of Urology, University of Health Sciences, Sultan Abdulhamid Han Training and Research Hospital, Istanbul Uskudar Tr- 34668 Istanbul, Turkey, Tel: +90 5065366134; Email: drserkanakan@hotmail.com

\begin{abstract}
Pyogenic granuloma is a benign soft tissue tumor in the skin and mucous membrane. It occurs due to acute/chronic local irritation, trauma or hormonal factors. Pyogenic granulomas are generally observed in head and neck areas in children and young adults. It is difficult to distinguish pyogenic granuloma from other vascular and malignant lesions due to its histological characteristics. Here in, we present a 69 year old male patient referred to our hospital with a lesion in the diameters of $12 \times 9 \mathrm{~mm}$ on the ventral side of the sulcus coronarius. Even though the age of the patient, lesion location and aetiology were not usual in the literature, the case was reported as pyogenic granuloma due to the histopathological excision examination.
\end{abstract}

Keywords: Penis; Pyogenic granuloma; Surgical excision

\section{Introduction}

Pyogenic granuloma (PG) is a skin and mucous membraneoriginated benign soft tissue tumor with acute/chronic local irritation, trauma or hormonal factors in etiology. It is generally seen in the second and third decades of life in neck and head area, especially the mouth. Lesions are generally pink-purple colored, smooth-bright surfaced and stemmed. They generally grow slowly and rarely exceed $10 \mathrm{~mm}$. Symptoms related to these lesions with a tendency for bleeding differ according to the area they are located and presence of ulceration. 69 year old case with PG in penis corpus was presented together with literature.

\section{Case Presentation}

A 69 years old male patient was referred to our clinic with painless mass complaint which was present for the last six months and growing in the last two months. On the physical examination, a regular bordered, non-ulcerated mass with a lesion in the diameters of $12 \times 9 \mathrm{~mm}$ on the ventral side of the sulcus coronarius (Figure 1). No previous infections or traumas were defined. There were no previous comorbidities (diabetes mellitus, coronary artery diseases, etc.) other than hypertension. The patient had no history of medication. The lesion was not painful or bleeding and the patient had no complaints other than difficulty during sexual intercourse and cosmetic problems. In laboratory findings; hemogram: $13.59 \mathrm{~g} / \mathrm{dL}$, white blood cells: $9.5 \mathrm{~K} / \mathrm{uL}$, platelet: $420 \mathrm{~K} / \mathrm{uL}$, creatinine: $1.1 \mathrm{mg} / \mathrm{dL}$, c-reactive protein: $0.36 \mathrm{mg} / \mathrm{dL}$. No bacteria were seen in the urine culture. Serological tests were negative Venereal Diseases
Research Laboratory test (VDRL): negative; the Rapid Plasma Reagin test (RPR): negative; T. pallidum Haemagglutination test (TPHA): negative; Human Immunodeficiency Virus test (ELISA): negative. We performed excisional biopsy considering surgical margins and the patient was discharged from the hospital in postoperative 24th hours. After histopathological examination, the lesion was reported as pyogenic granuloma (PG) (Figure 2). No recurrence was observed during the two-year follow-up of patient.

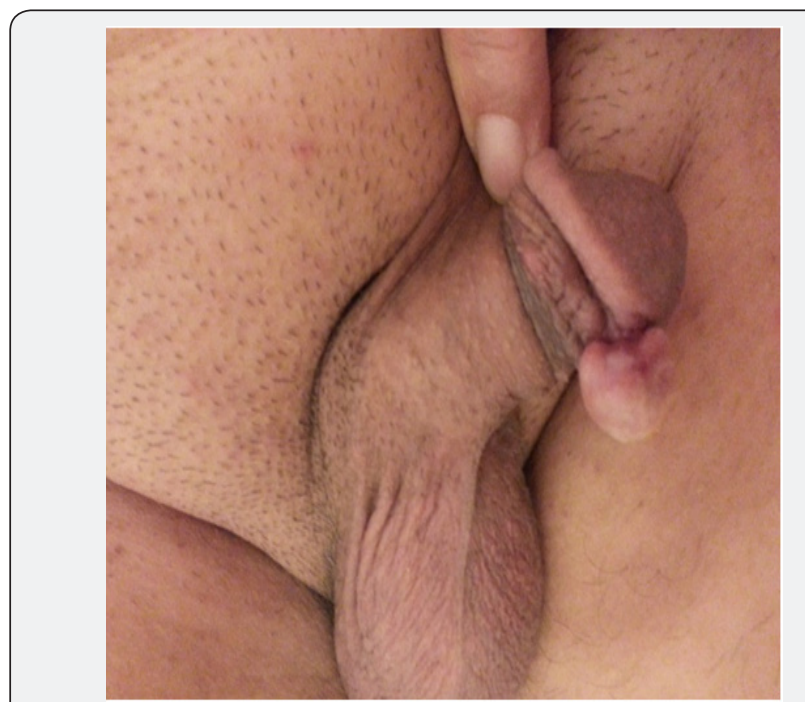

Figure 1: A lesion in the diameters of $12 \times 9 \mathrm{~mm}$ on the ventral side of the sulcus coronaries. 


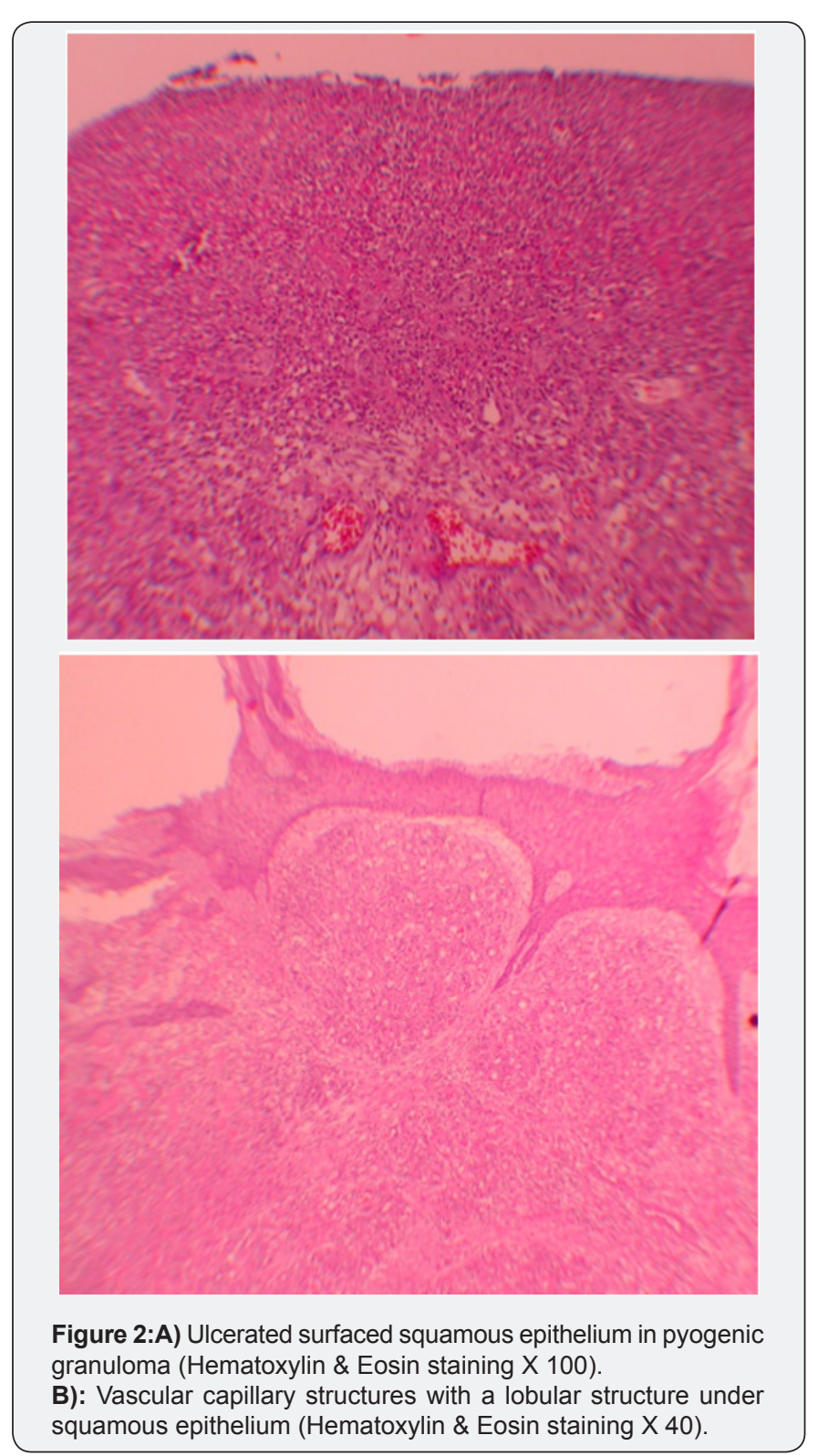

\section{Discussion}

Pyogenic granulomas are benign vascular proliferations also called as lobular capillary hemangioma or granuloma telengiectaticum. Its ratio in all skin nodules in a series containing 408 cases was reported as $0.5 \%$ [1]. Etiologic factors can be listed as follows; acute/chronic irritation, microtraumas, foreign objects, poor hygiene, vasculitis, oral contraceptive use and hormonal factors such as pregnancy. They are not bacteriaoriginated even though they occur more easily in infected areas [2]. While these are most commonly located in head and neck area; mainly fingers, palm, chest area and extremities; mucosal lesions can be found in oral cavity, gingiva, nasal cavity, larynx, conjunctiva and rarely in gastrointestinal system [1].

Overproduction of angiogenic factors or cytokines after a local trauma promotes PG growth. PG prevalence increases during pregnancy. These lesions can grow due vascular factors of oestrogen [3]. Again in the studies on tissue level, it is considered that nitric oxide synthase, vascular endothelial growth factor, fibroblast growth factor and connective tissue growth factor are responsible for angiogenesis and growth in PG [4]. Generally, the dimension of these slowly growing lesions changes between $5 \mathrm{~mm}$ and $10 \mathrm{~mm}$ and rarely reach dimensions over $25 \mathrm{~mm}$ [5]. The lesion in our case was $12 \times 9 \mathrm{~mm}$ which is among standard dimensions. But the significance of our case was the serious growth in the lesion in the last two months.

PG surface is generally ulcerated. Characteristic lobular proliferation of microvascular new vascular formations, ulceration and stromal edema accompanying surface neutrophil infiltration are the histopathological findings of PG [6]. In the histopathological examination of our case, erythrocytes containing mature-appearing vascular structures lobularly located below squamous epithelium were observed. Squamous epithelium had an ulcerated appearance on biopsy surface (Figure 2).

Although they are mostly known as benign tumors, it was reported that they may cause damage such as localized bone resorption in surrounding tissues [6]. The distinctive diagnosis based on histoptahological features from hemangioma, seborrheic keratosis, melanocytic nevus and spitz nevus among benign lesions and squamous cell carcinoma, basal cell carcinoma, metastatic carcinoma, kaposi sarcoma, amelanotic melanoma, angiosarcoma, Non-Hodgkin lymphoma, metastatic cancer and malignant melanoma among malignant lesions is made.

No previous infections or traumas were defined in our case. But there was a circumcision history due to cultural reasons, performed nearly sixty years ago. When the lesion's proximity to the circumcision incision line is considered it may be thought to be consistent with the trauma etiology in the literature. But this operation was performed sixty years ago. Apart from this, sexual intercourse of the sexually active patient with his partner can be accepted as a kind of microtrauma.

There are a limited number of penile PGs in literature and these are in pediatric and young adult age groups in line with general PG knowledge. A 13-year old child patient was presented as a case of phimosis-related PG over penis. Pathology was related to smegma accumulation-related inflammation and chronic local trauma in this case [7]. Again in a three year old pediatric case, penis PG occurring after circumcision was presented [8]. In 2017, Hadzavdic et al. [9] reported a penile PG grown on granulation tissue about one year after primary syphilis lesion in a 44-year-old patient [9] As far as we know, our 69 year old male case is the first genital PG case reported in this elderly age group and 12 th penile PG in overall.

Diagnosis is made by surgical excision and histopathologic examination. In another case, however, it was stated that a 
vasculogenic lesion can be shown by ultrasound scan performed before excision [10].

Different alternatives are available according to PG location and size in PG treatment. Follow-up is possible if itis asymptomatic and small. Although the primary treatment method is surgical excision; cryosurgery, YAG laser and sclerotherapy (ethanol, corticosteroid, sodium tetra decile sulphate) are other treatment approaches. Lowest recurrence rates are observed in surgical excision [11]. Ichimiya et al. [12] reported pure ethanol injection application as an alternative treatment method which is less invasive than surgical excision in pyogenic granuloma patients with recurrence due to inadequate cryosurgery [12] Again 5\% topical imiquimod application was recently recommended with optimal results in PG treatment [13].

Although recurrence ratio changes between 3 and 23\% in the studies in literature, it was presented as $14.88 \%$ in a serial of 215 cases [14]. This data demonstrates that these patients should be followed-up for recurrence and warned against predisposing factors (infection, local irritants and trauma) and recurrence possibility should be decreased. No recurrence was observed during the two-year follow-up of our case.

\section{Conclusion}

We report a PG that grows on the ventral side of the elderly patient's penis. No recurrence was observed during the twoyear follow-up of our case treated by surgical excision. We recommend excision of the penis PG because of its advantages such as single-stage treatment, low recurrence rates and pathological evaluation

\section{References}

1. Giblin AV, Clover AJ, Athanassopoulos A, Budny PG (2007) Pyogenic granuloma - the quest for optimum treatment: Audit of treatment of 408 cases. J Plast Reconstr Aesthet Surg 60(9): 1030-1035.
2. Ozbayrak S (2003) Oral Diagnosis Criteria, Differential Diagnosis and Treatment Approaches. ( $1^{\text {st }}$ edn), Quintessence Publisher, SisliIstanbul, Turkey, pp. 196.

3. Gonçales ES, Damante JH, Fischer Rubira CM, Taveira LA (2010) Pyogenic granuloma on the upper lip: an unusual location. J Appl Oral Sci 18(5): 538-541.

4. Zabollos P, Llambrich A, Cuellar F, Puig S, Malvehy J (2006) Dermoscopic findings in pyogenic granuloma. Br J Dermatol 154(6): 1108-1011.

5. Al-Khateeb $\mathrm{T}$, Ababneh $\mathrm{K}$ (2003) Oral pyogenic granuloma in Jordanians: a retrospective analysis of 108 cases. J Oral Maxillofac Surg 61(11): 1285-1288.

6. Cherit JD, Miranda MP, Gamboa LR, Marin RR (2006) Giant gravidarum granuloma of the scalp. Gac Med Mex 142(5): 411-413.

7. Spinelli C, Di Giacomo M, Bertocchini A, Loggini B, Pingitore R (2009) Multiple pyogenic granuloma of the penis in a four-year-old child: a case report. Cases J 2: 7831

8. Eickhorst KM, Nurzia MJ, Barone JG (2003) Pediatric pyogenic granuloma of the glans penis. Urology 61(3): 644.

9. Hadzavdic LS, Bartolic L, Doko K, Skerlev M (2018) Pyogenic granuloma of the penis following chancre. J Eur Acad Dermatol Venereol 32(3): e95-e97.

10. Katmeh RF, Johnson L, Kempley E, Kotecha S, Hamarneh W, et al. (2017) Pyogenic Granuloma of the Penis: An Uncommon Lesion with Unusual Presentation. Curr Urol 9(4): 216-218.

11. Moon SE, Hwang EJ, Cho KH (2005) Treatment of pyogenic granuloma by sodium tetradecyl sulfate sclerotherapy. Arch Dermatol 141(5): 644-646.

12. Ichimiya M, Yoshikawa Y, Hamamato Y, Muto M (2004) Successful treatment of pyogenic granuloma with injection of absolute ethanol. J Dermatol 31(4): 342-344.

13. Fallah H, Fischer G, Zagarella S (2007) Pyogenic granuloma in children: Treatment with topical imiquimod. Australas J Dermatol 48(4): 217220.

14. Krishnapillai R, Punnoose K, Angadi PV, Koneru A (2012) Oral pyogenic granuloma- a review of 215 cases in a South Indian Teaching Hospital, Karnataka, over a period of 20 years. Oral Maxillofac Surg 16(3): 305309.

\section{Your next submission with Juniper Publishers will reach you the below assets}

- Quality Editorial service

- Swift Peer Review

- Reprints availability

- E-prints Service

- Manuscript Podcast for convenient understanding

- Global attainment for your research

- Manuscript accessibility in different formats

( Pdf, E-pub, Full Text, Audio)

- Unceasing customer service

Track the below URL for one-step submission https://juniperpublishers.com/online-submission.php 